\title{
Geo-historical Appraisal of Embankment Breaching and Its Management on Active Tidal Land of Sundarban: A Case Study in Gosaba Island, South 24 Parganas, West Bengal
}

\author{
Soumen Ghosh ${ }^{+*}$ and Biswaranjan Mistri ${ }^{*}$
}

\section{Abstract}

The embankments act as a life line for deltaic people of the Sundarbans. The reclamation of immature land through the construction of embankment without proper planning has been increasing the vulnerability of embankment breaching due to various natural and anthropogenic causes. The construction and maintenance of embankments are difficult tasks without prior knowledge about the mode of vulnerability and ground situations of the sites. To understand the scenario of embankment breaching and its recent management strategy, an intensive field survey was conducted to comprehend the underlying reasons for embankment breaching and its management techniques at the ground level. The modern techniques were also incorporated to identify the vulnerable sites of river bank erosion. The study reveals that the southern part of the delta is more vulnerable due to intensive river bank erosion. To understand potential capabilities of these embankments to combat against fluvio-hydrological challenges, a sequential change of embankment construction from historical past to present and recent scientific engineering model of Aila Dam has been chalked out in this study. The present study is an attempt to understand the geo-historical perspectives of embankment construction and to identify the vulnerable coastal zone of Gosaba Island of Sundarban. The study also aims to illustrate the modern techniques of embankment management for its longevity in such a dynamic land.

Keywords: Embankment Breaching; Vulnerability Assessment; Fluvio-hydrological Challenges; Management Techniques; Sundarban; 24 Parganas, West Bengal; India

\footnotetext{
${ }^{\dagger}$ Research Scholar, Department of Geography, The University of Burdwan, West Bengal 713104, India

${ }^{*}$ Corresponding Author, Email: ghoshsoumen864@gmail.com

${ }^{¥}$ Associate Professor, Department of Geography, The University of Burdwan, West Bengal 713104, India, Email: brmistri@gmail.com

(C) Ghosh \& Mistri. This is an Open Access article distributed under the terms of the Creative Commons Attribution License (http://creativecommons.org/licenses/by/2.0), which permits unrestricted use, distribution, and reproduction in any medium, provided the original work is properly cited.
} 


\section{Introduction}

Sundarban is the largest deltaic part of the Ganga-Brahmaputra and Meghna River System, spanning over both India and Bangladesh (O'Malley, 1914). The total geographical area of the Indian part of Sundarban is 4,267 sq. Km and the total population consists of 4.5 million (WWF Report, 2010). Agriculture is the mainstay economic activity of Sundarban, where cultivation was possible through the construction of embankment along coasts (Banerjee, 1998). The average elevation of the delta is 2.8-3.0 meter and the majority of the inhabited island remains below the high tide line (Mistri, 2014). Land reclamation had started in Sundarban during 1870 by the erection of embankment to protect agricultural land from saline water intrusion but still tidal water frequently enters into coastal villages due to poor management of the embankment and causes colossal damage to agriculture, settlement and human-made structures (Das et al., 2012). The total length of embankment in Sundarban is almost $3500 \mathrm{sq}$. Km and remains in a vulnerable situation along its maximum length (Sarkar et al., 2016). The management of embankments is the responsibility of village Panchayat but technical part of maintenance and the construction of the embankment is assisted by Irrigation and Waterways Department (IWD), Government of West Bengal (WB) (Das et al., 2012). The frequent occurrence of tidal surge over the Bay of Bengal increases the tidal amplitude and changes tidal asymmetry of the rivers (Das and Maity, 2008). Therefore, breaching of the embankment is a common phenomenon in the coastal region of Sundarban and comes out as a serious threat for coastal inhabitants during catastrophic events. In this ground, the present study deals with the geohistorical perspective of embankment construction of the Gosaba island of Sundarban. In doing so, it aims to understand the vulnerability of embankment breaching, an engineering model of embankment and management strategy at ground level to protect life and property of estuarine people from the weakness of embankment breaching.

The research begins with a review of the literature followed by a detailed description of the study area, methodology and major objectives of the research. The research then turns to discuss the geo-historical background of the Gosaba Island taking references from the contribution of Sir Daniel Hamilton on the socioeconomic development of the Block. In the next section, the Functional Framework of IWD, Government of WB draws out the details to study the role of government officials in the construction and management of embankments based on administrative hierarchy. After that, before identifying the vulnerable zone of the embankment breaching in various parts of the delta, mechanism and engineering model of embankments are discussed in details to understand the recent technological advancement of embankment model. At last, based on an in-depth analysis of research objectives, the research urges for giving importance on grass root level management of embankment through the participation of local community.

\section{Review of Literature}

The large scale construction of embankments in Sundarban began during the British colonial periods to protect the agricultural land from saline water intrusion (Sarkhel, 2012). There are many studies focused on embankment breaching and management related issues of embankment such as Das and Maity (2008); Das and Das (2015); Dhara and Paul (2016); Das (2016). There are several notable works obtained discussing the geo-historical background of the Sundarban and the role and function of embankment on day to day life of coastal communities (O'Mally, 1914; Banerjee, 1998; Sarkhel, 2013). The efficiency of embankment management and its mechanism of breaching depend on various factors such as river hydraulics and estuarine process (Das and Maity, 2012). The location-specific vulnerable zone in different island units of Gosaba has been clearly identified using modern techniques with 
field investigation. It helps the planners as well as engineers to identify the most vulnerable zones in Gosaba, which are quite sensitive to embankment breaching because of active riverbank erosion. The methodology to identify vulnerable coastal zones is quite identical with the previous works of Gopinath and Seralathan (2005); Ghosh and Mukhopadhyay (2016). There are also some remarkable works regarding management strategies of embankment such as Ghosh et al.(2015); Lakshmi and Edward (2010); Das et al. (2012). These studies are quite helpful to understand the geo-historical appraisal of embankment breaching from the historical past to present in such a dynamic land of Sundarban. A brief description of the study area is outlined below.

\section{The Study Area}

Sundarban is topographically low lying flat alluvial plain crisscrossed by several interlinking tidal creeks, canals and outlets (Bagchi, 1944, Das and Das, 2015). As stated above, the present study area is the Gosaba C.D. Block, which is one of the critical blocks of the Sundarban and lies within Canning Sub Division of South 24 Parganas district of West Bengal, India (Figure 1). The areal extension of Gosaba is $21^{\circ} 54^{\prime} \mathrm{N}$ to $22^{\circ} 08^{\prime} \mathrm{N}$ and $88^{\circ} 29^{\prime} \mathrm{E}$ to $88^{\circ} 49^{\prime} \mathrm{E}$. The average elevation of Gosaba C.D. Block is 6 metre from the mean sea level. River Bidya bounds the region in the west and rivers Gomar and Raimangal in the east. Gosaba block has 14 Gram Panchayats (Amtali, Bali I and II, Bipradaspur, Chhota Mollakhali, Gosaba, Kachukhali, Kumirmari, Lahiripur, Pathankhali, RadhanagarTaranagar, Rangabelia, Satjelia and Sambhunagar) and 50 inhabited villages (Human Development Report, 2009). Total area of the block is $296.43 \mathrm{sq} . \mathrm{km}$ and population density is 830 people /sq. km (Census of India, 2011). The tropical monsoon climate dominates the region. The mean annual rainfall is $180-200 \mathrm{~cm}$ and $80 \%$ of the rain occurs during monsoon season (June to October). The annual temperature ranges between $21^{\circ} \mathrm{C}-32^{\circ} \mathrm{C}$ and relative humidity varies from 70 to $80 \%$. The key objectives of the study are as follows:

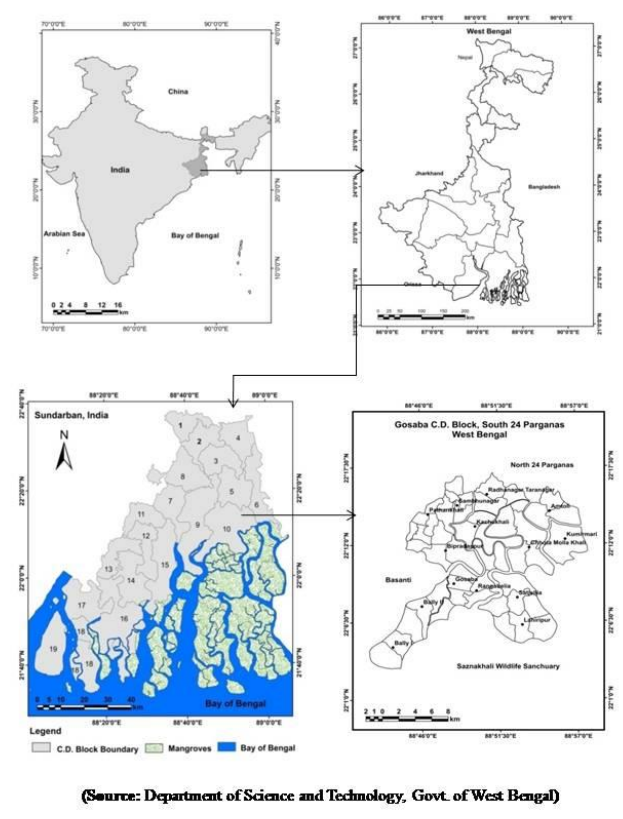

Figure 1: Location Map of the Study Area Source: Department of Science and Technology, Government of West Bengal 


\section{Objectives of the Study}

- To draw out the scenario of geo-historical appraisal of embankment construction in the dynamic land of Sundarban

- To identify the vulnerable zone of embankment breaching at Gram Panchayat level and significant causes associated with it.

- The management of embankment breaching at ground level and recent engineering model of the embankment to combat against flood vulnerability.

\section{Methodology and Collection of Data}

This study is based on both primary and secondary data. Primary data was collected through a field survey using questionnaire and interview method (Size of sample-107). The secondary data was collected from different sources as shown below (Table 1).

\begin{tabular}{|c|c|c|}
\hline Type of Data & Source of Data & Year \\
\hline \multirow[t]{2}{*}{ Population Related Data } & Census of India & 2001, 2011 \\
\hline & $\begin{array}{l}\text { Human Development Report, South } 24 \\
\text { Parganas }\end{array}$ & 2009 \\
\hline $\begin{array}{l}\text { Geo-historical Appraisal of } \\
\text { Embankment }\end{array}$ & $\begin{array}{l}\text { Rivers of Bengal, Bengal District Gazetteers } \\
\text { by L. S.S O'Mally } \\
\text { Historical books and journals }\end{array}$ & 1914 \\
\hline Irrigation and Embankment & $\begin{array}{l}\text { Gosaba, Irrigation Subdivision office } \\
\text { Irrigation and Waterways Department, WB } \\
\text { Sechpatra, IWD, WB }\end{array}$ & $2011-2016$ \\
\hline $\begin{array}{l}\text { Embankment Breaching and } \\
\text { Vulnerability }\end{array}$ & $\begin{array}{l}\text { Satellite images and field survey } \\
\text { Landsat MSS: Row \& Path - } 148 \text { \& 45; Date of } \\
\text { Acquisition - 05-Nov, } 1972 \\
\text { Landsat } 8 \text { OLI: Row \& Path } 198 \text { \& 45, Date of } \\
\text { Acquisition - 08-Nov, } 2017\end{array}$ & 1972 and 2017 \\
\hline
\end{tabular}

The data collected from different sources were arranged, analysed and represented systematically and scientifically to fulfil the objectives of the research. To identify the vulnerable zone of embankment breaching image overlay analysis was precisely conducted in Arc GIS environment using digitised coastal boundaries of the block extracted from multitemporal satellite images (Landsat MSS of 1972 and Landsat $8 \mathrm{OLI}$ of 2017). The zones were identified as vulnerable where the river is progressive towards land and causes rapid land loss due to embankment breaching. Field verification was also conducted to verify the result of vulnerability assessment to make the study more accurate and reliable in the scientific ground. The results of the study are discussed below.

\section{Results and Discussion}

\section{Geo-historical Appraisal of Embankment Construction}

The land reclamation process was started in Sundarban during the British colonial empire in 1870. The rapid population growths, conversion of agricultural land to fisheries and build-up areas, traditional mono-cropping activities are the dominant land use pattern of the study area. Before the expansion of the British colonial period, Sundarban was known as 'Forbidden Land for Humankind' and 'The Land Dopulated by Mugs' (Gour, 2012, Dutta, 2014). In each phase of land reclamation, the people have neglected the vital role of these tidal creeks or channels (Banerjee, 1998). The frequent occurrence of the flood is the main curse for deltaic people, and tidal channels increased the 
intensity of flood vulnerability. The unscientific processes of land reclamation through the construction of embankments for some temporary benefits have been affected by the natural equilibrium process and livelihood of rural people.

Sir Daniel Hamilton, a Scottish Businessman, took a lease of 9000 acres of land from the British Government in the Sundarban area (lots no. 143 and adjacent 148 for forty years) (Dutta, 2014). His idea was to develop Gosaba as a self resilient village based on the co-operative system. Sir Daniel took the initiative to clear the mangrove forests and raised the level of marshy land by erecting embankments to prevent saltwater intrusion in agricultural land. Initially, 900 people were living in the delta in 1909. Most of the inhabitants migrated from Medinipur, Jharkhand and Orissa as the mother earth was not favourable for human habitation. However, over time, thousands of immigrants settled in the delta. There are four types of embankment commonly found in Sundarban (Table 2).

\begin{tabular}{|c|c|c|c|}
\hline Embankment Height & Type of Embankment & $\begin{array}{c}\text { Length of } \\
\text { Embankment }\end{array}$ & $\begin{array}{l}\text { Position of } \\
\text { Embankment }\end{array}$ \\
\hline 3.67 metres & Earthen embankment & 40 km & $\begin{array}{c}\text { Coast exposed to } \\
\text { wave }\end{array}$ \\
\hline 3.00 metres & Earthen embankment & $1560 \mathrm{~km}$ & Large river \\
\hline 2.70 metres & Brick pitching & $1200 \mathrm{~km}$ & Island margins \\
\hline 2.00 metres & Boulder pitching & 700 km & Small channels \\
\hline
\end{tabular}

The total length of the embankment in Sundarban was 3638.18 km in 2010 (Sarkar et al., 2016). The Gosaba Island has $372.5 \mathrm{~km}$ length of embankments that is the highest among the thirteen CD block of South 24 Parganas (Das and Das, 2015). During the colonial period, Zamindars or landlords took the responsibility of embankment maintenance, but after the abolition of the Zamindari system, the responsibility of embankment maintenance had fallen on IWD. The primary functions of IWD are as follows:

- Embankment construction and maintenance.

- Drainage problem mitigation.

- Anti river bank erosion management

- Management of anti sea erosion

- Dam construction and maintenance of lock gates

\section{Functional Framework of IWD, Government of West Bengal}

There is a functional administrative hierarchy of IWD, WB (Figure- 2). The responsibility for implementation of the developmental plan, Assistant Engineer, directly works under the supervision of the executive officer and chief engineer of the district. The Assistant Engineer is responsible not only for the proper execution of works, which are entrusted to his charge but also for the correctness and validity of the financial transactions connected therewith. The Assistant Engineer is also responsible for carrying out his functions and responsibilities through his subordinates following the approved specifications, designs, drawings, and rules and instructions in the departmental codes, manuals and technical circulars in force from time to time. Sub Assistant Engineer performs the following duties:

- Carry out survey and investigation of projects/schemes as per directions of his Superior officers and prepare drawings.

- Check the initial ground levels to visit the groundwork and layout before the start of the work.

- Maintain up to date account and other registers prescribed under the rules correctly.

- Take action to prevent encroachment on government lands. 


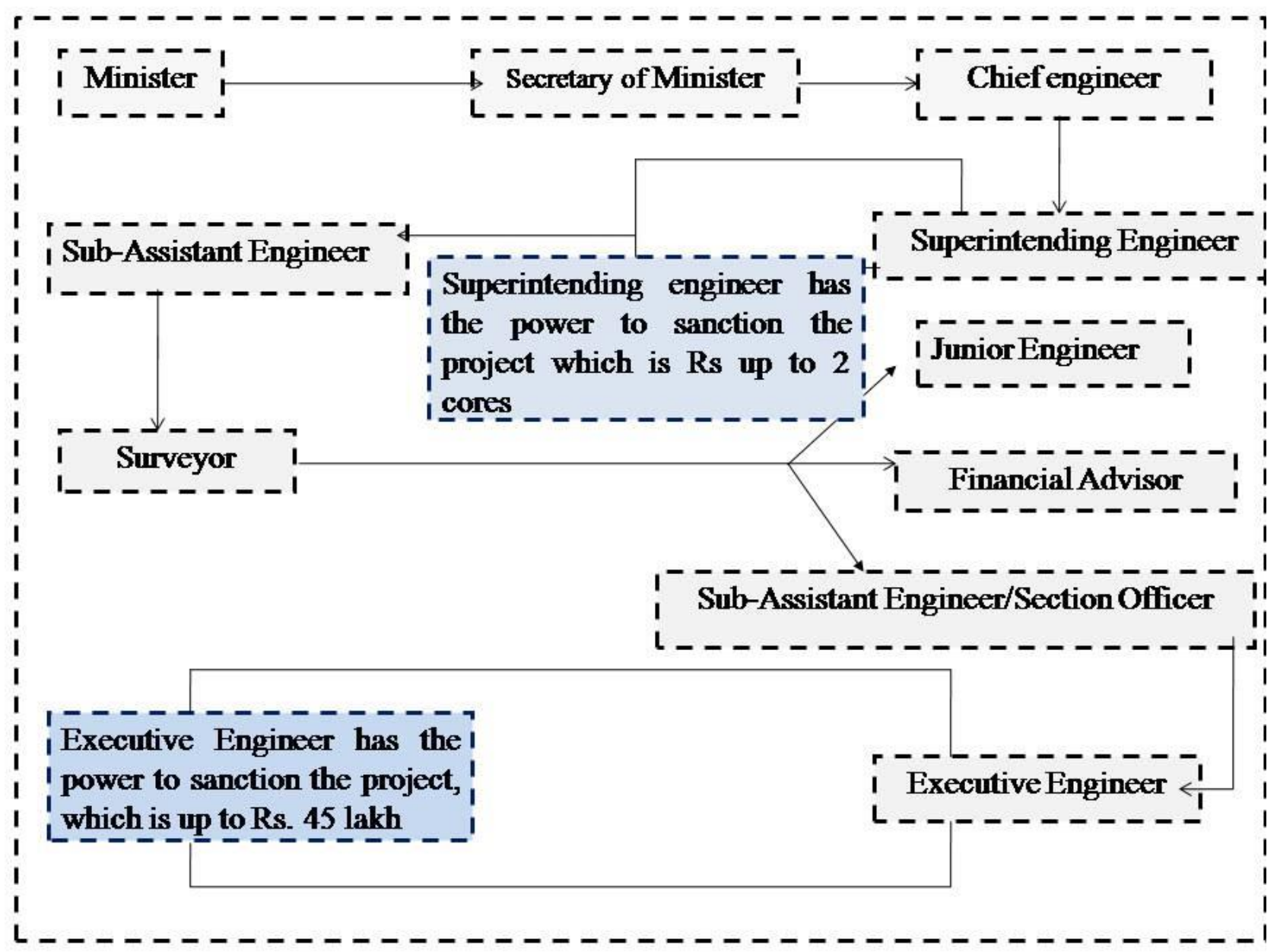

Figure 2: Administrative Functional Hierarchy of Irrigation and Waterways Department Source: IWD, WB

The Executive Engineer, in charge of a Division is responsible to his Superintending Engineer for the execution and arrangement of all works in his Division. His duties mainly include planning, investigation, construction and maintenance of all Engineering works entrusted to his charge and maintain the detailed accounts of expenditure. In particular, he shall-

Ensure that no work is started without a sanctioned detailed and accurate estimate, and no expenditure is incurred without obtaining funds.

Ensure that expenditure proposed during the financial year or different working seasons is based on such estimates so that a detailed review of progress subsequently is possible with reference to these estimates.

Periodical review of the physical and financial progress of development programme.

\section{The Scenario of Embankment Construction from Past to Present}

The erection of mud embankments began rapidly in the early 19th Century with the aim to protect agricultural land from tidal water intrusion. The maintenance of embankment was the responsibility of landlords according to the permanent settlement act of 1793 , but private participation regarding the management of embankment was very inadequate. Therefore, the responsibility of embankment maintenance was identified as public works by the Bengal embankment act of 1873 and responsibility vested to the state (Sarkhel et al., 2013). After independence, IWD took the responsibility of embankment construction and management jointly with village Panchayat. The importance of maintaining the embankments is hugely warranted to combat the challenges of sea-level rise and global climate change. There is a 
sequential change found in the construction of embankment during minutely field surveying

(Figure 3).
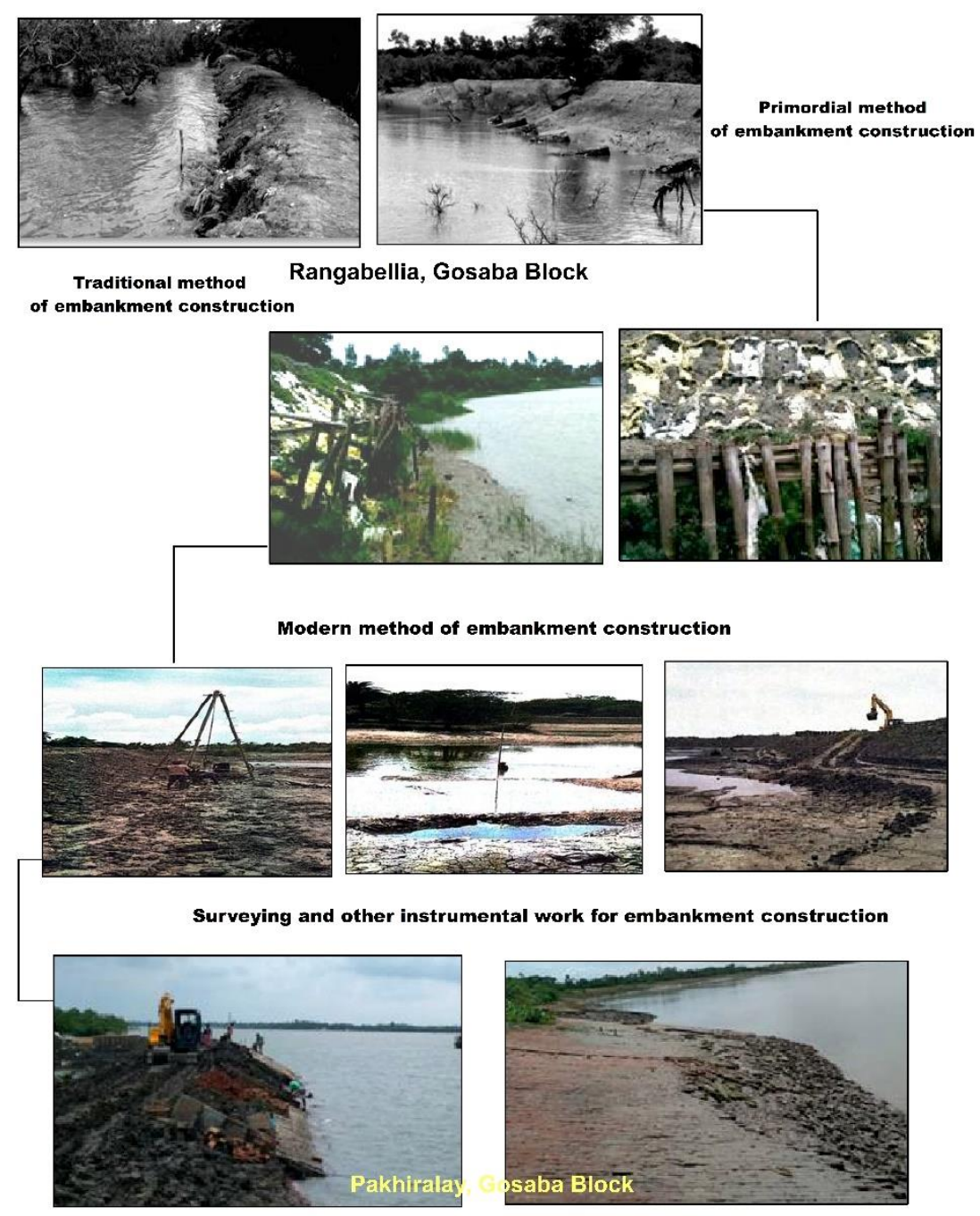

Block pitching

Figure 3: Embankment Construction from Past to Present Source: Field Survey (12-02-2019 to 20-02-2019)

\section{Mechanism and Engineering Model of Embankment}

Embankment may refer to a levee or an artificial bank, mainly elevated from the surrounding parts of the land to prevent flooding by a river, lakes or sea. Embankments may either made by earthen materials or bricks and concrete materials (Das, 2016). The construction of embankment in Sundarban is still a difficult task due to the hydro-geomorphic diversity of the land. The texture of the soil in the studied region is mainly silty clay and clayey soil. The bearing capacity of these types of soil is very low.
Therefore, technological expertise is required for heavy embankment construction. At present, synthetic Geotextile and Jute Geotextile are frequently used as filter layer in the embankment construction. The average height of typical embankment is 3 metre from mean sea level, protected by a small dwarf Bundh. This Bundh protects the main embankment from the direct tidal current. A sausage, made by brick blocks is constructed under the ground and below the riverward edge of the main embankment to increase the longevity of the embankments. The river side and country side 
slope of the embankment are 3:1 and 2:1 respectively. On 23 May 2009, Aila, a severe tropical cyclone wind speeds of $110 \mathrm{kmh}$ (70 $\mathrm{mph}$ ) produced not only natural disaster but proved that the height of the embankments fail to protect the deltaic people of Sundarban during environmental extremes as the region remains below the high tide line. Therefore, the heights of the embankments have been raised in some places from 3 metre to 6.5 metre to save the inhabited coastal part from flood water inundation. This type of elevated dam is locally known as Aila dam (Figure 4). The Aila dam is commonly found in various parts of Gosaba Island like Bagbagan, Bally and Satjelia. However, the construction and management of the embankments in these dynamic islands is still a big challenge for engineers and planners.

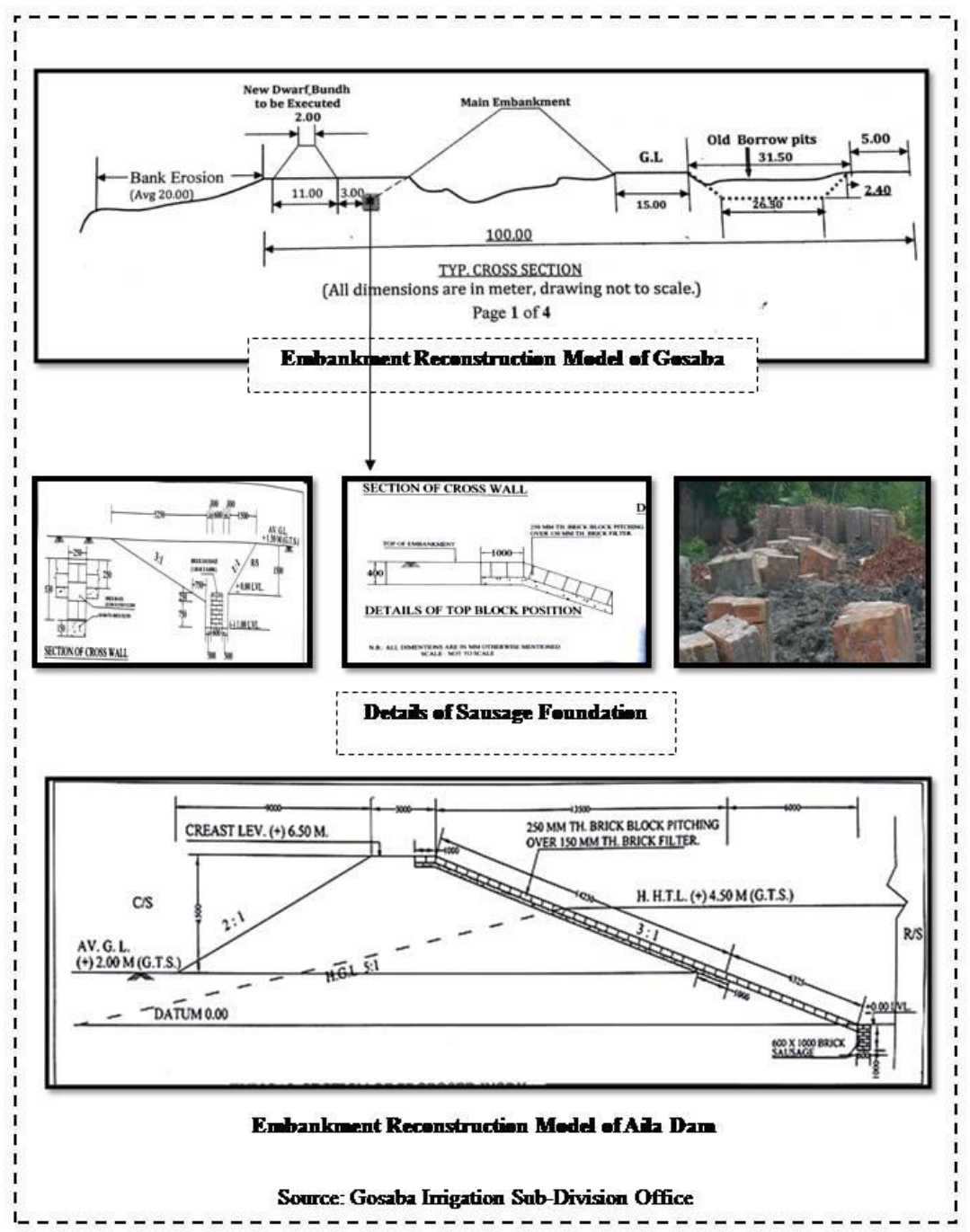

Embankment Reconstruction Model of Aila Dam

Figure 4: Recent Engineering Model of Embankment Source: Gosaba Irrigation Sub-Division Office

\section{Zone of Embankment Breaching}

The tidal action of the river strongly influences the entire Gosaba Island. The intensity of erosion and accretion process varies in different parts of the delta. The southern part of the delta is more prone to intensive erosion in comparison to northern parts (Figure- 5). During monsoon season, the vast water pressure in the river and occasional tidal surge make the marginal island more vulnerable. The rate and intensity of the river bank erosion also depend on various other factors like amount and frequency of water 
supply, sediment supply, geology, soil characteristics, vegetation cover and surface land-use system. Erosion zone has been identified through the superimposition of vectorised multi-temporal satellite images (Ghosh and Mukhopadhyay, 2016). The shoreline movement towards the river is identified as the depositional zone. However, when the shoreline moves backwards and the river moves forward, the area is demarcated as erosional zone (Srivastva et al., 2005).Gram Panchayat (GP) wise vulnerable zone of embankment breaching has been measured with the help of satellite imageries using Arc GIS and necessary field survey has also been conducted to validate the ground reality which is shown in Table 3.

Table 3: Vulnerable Zone of Embankments

\begin{tabular}{|c|c|c|c|c|}
\hline SI. No. & G.P. Name & River/Khal & Bank & $\begin{array}{l}\text { Length of Vulnerable } \\
\text { Zone (In Metre) }\end{array}$ \\
\hline 1 & Amtoli & Raimangal river & Left & 1709 \\
\hline 2 & Bally I & Gomar Khal & Right & 4817 \\
\hline 3 & Bally II & Bidya river & Left & 6723 \\
\hline 4 & Bipradaspur & Bidya river/Karatal Gang & Right/Left & 4071 \\
\hline 5 & Chotomollakhali & Bidya river/Sarsa Gang & Left/Right & 2663 \\
\hline 6 & Gosaba & Bidya river/Gomar Khal & Left/Right & 6757 \\
\hline 7 & Kachukhali & $\begin{array}{l}\text { Durgamandal Khal/ } \\
\text { Bidya river }\end{array}$ & Right/right & 1415 \\
\hline 8 & Kumirmari & $\begin{array}{l}\text { Sarsa Gang/ Banga Khal/ } \\
\text { Korankhali Khal/ Puinjali } \\
\text { Gang }\end{array}$ & $\begin{array}{l}\text { Left/Right/ } \\
\text { Right/Left }\end{array}$ & 7531 \\
\hline 9 & Lahiripur & $\begin{array}{l}\text { Kapura Gang/Saznakhali } \\
\text { Khal }\end{array}$ & Right/Right & 5419 \\
\hline 10 & Pathankhali & Maukhal & Left & 1475 \\
\hline 11 & Rangabalia & Bidya river/Satjali Khal & Left/Right & 10,170 \\
\hline 12 & $\begin{array}{l}\text { Radhanar } \\
\text { Tarangar }\end{array}$ & East Radhangar Khal & Right & 103 \\
\hline 13 & Sambhunagar & Pathankhali Khal & Left & 1270 \\
\hline 14 & Satjelia & Satjali khal/Garal Gang & Left/Right & 5806 \\
\hline
\end{tabular}

Source: Calculated by the Authors 


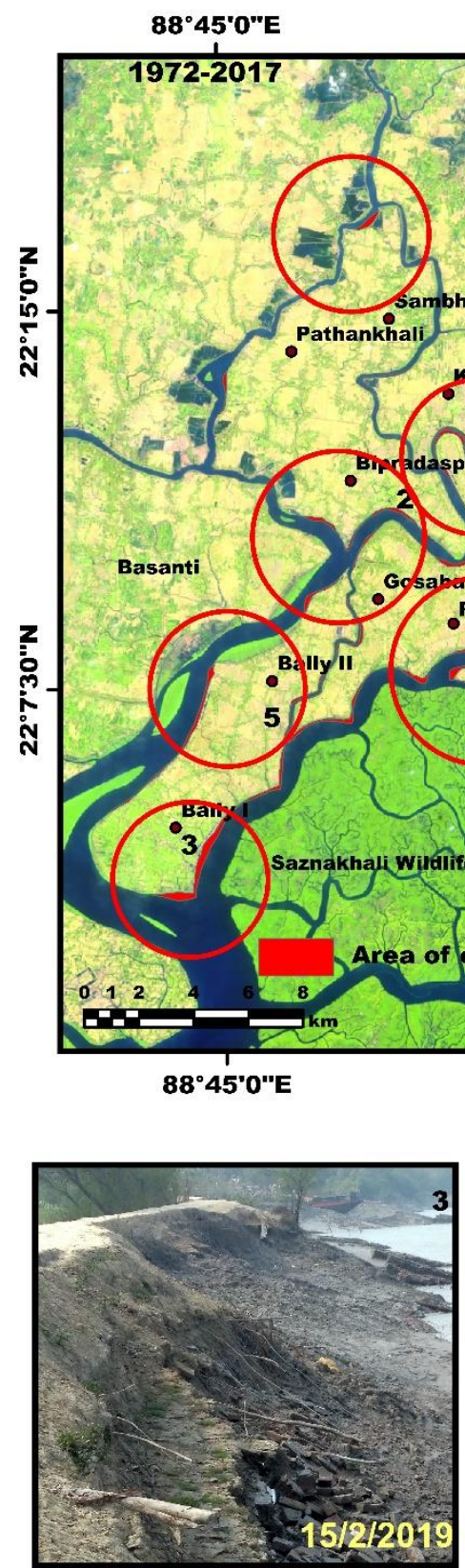

Amlamethi

8852'30"E

North 24 Parganas Radhanagar Taranaga inagar kachukhali

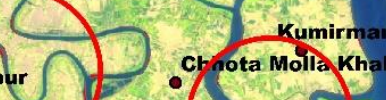
4. (1) Rangabelia Satjellia Lahiripur
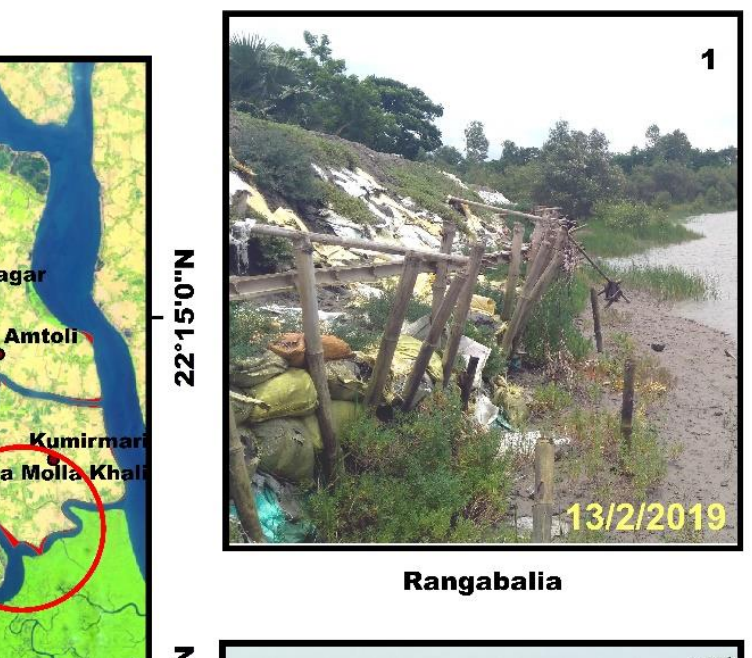

Rangabalia

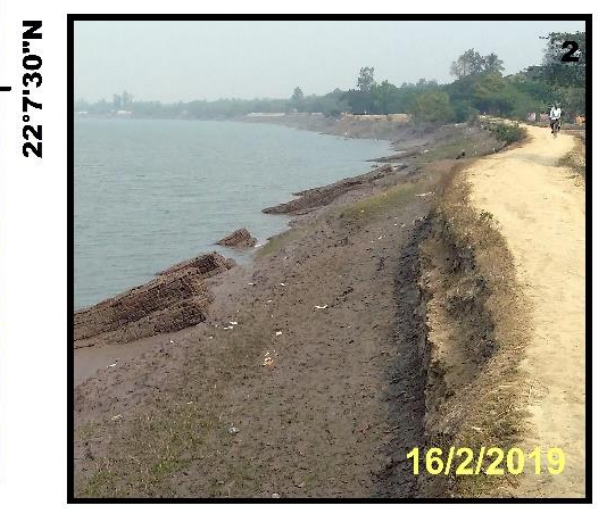

Manmathanagar

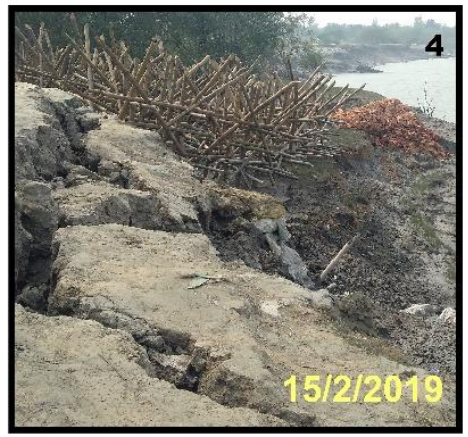

Bagbagan

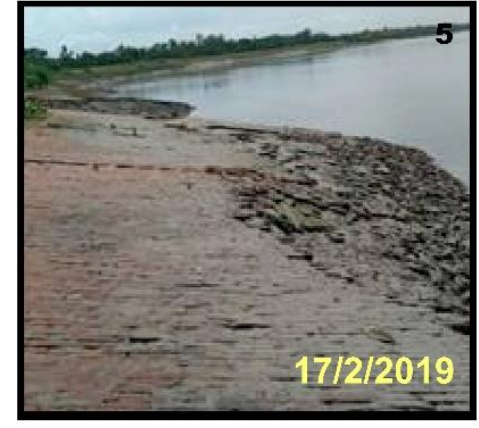

Bijoynagar

Embankment breaching

Figure 5: Vulnerable Sites of Embankment Breaching Source: Authors

\section{Causes of Embankment Breaching}

The hydro-geomorphic characteristics of the dynamic estuarine land of Gosaba are the main hindrances for management of the embankments. The embankments are the artificial construction of the wall surrounding the large rivers and creeks (khals) which separates the natural and cultural entity of estuarine land. There are both natural and anthropogenic causes responsible for embankment breaching. 
The primary natural and anthropogenic causes responsible for embankment breaching are as follows:

\section{Natural Causes}

- The unscientific constructions of the embankment along tidal channels increase the sedimentation process within the river bed. The depth of the river bed is gradually increasing than the surrounding floodplain area. During high tide, the water level rises at least above 2 metres from the adjoining floodplain. The tidal inflow of water is transforming into a tidal bore during environmental extremes which frequently causes embankment breaching in the estuarine area.

- The construction of several longitudinal and cross-sectional embankments leads to complete choking of channels. Tidal channels have lost their lateral connectivity with time. Hence, tidal water is not able to flow freely in the inland river system. Indeed, tidal magnitude and hydraulic pressure in the major river of Sundarban are rapidly increasing due to the concentration of excess water. As a result, when the pressure exceeds its shear strength, it causes embankment breaching.

- The most of earthen embankments of Sundarban were built during the British Colonial period. These embankments are technologically weak as they are constructed by local soil and mud. The continuous tidal surges and constant swirling of river currents increase toe erosion and scouring in embankments which leads to the frequent occurrence of embankment breaching.

- The intensity and frequency of cyclone occurrence over the Bay of Bengal have been rapidly increased in recent decades due to the rise of sea surface temperature. Embankments are tremendously prone to breaching during cyclonic storms. The occurrence of cyclone in 1988, 1989, 1995 and 2009 was severely damaged and breached embankments in various Islands of Gosaba.

- The rapid deforestation of mangrove forests plays an essential role in embankment breaching. Mangrove roots protect soils from erosions. However, excessive deforestation of mangrove forests increases the intensity of embankment breaching due to massive soil erosion.

\section{Anthropogenic Causes}

- Population pressure in Gosaba Island has been rapidly increased in the last centuries. People primarily live adjacent to river banks and tidal channels to meet their primary livelihood. The unsystematic land-use practices and unplanned settlement in concave meandering bends of rivers make the embankments highly unstable.

- The construction of narrow channels through embankments for maintaining water circulation system between land and river often leads to embankment failure during high tides, storm surges and heavy rainfall especially in monsoon season.

- Several sluice gates have been constructed at the mouth of tidal creeks to drain out excess water of countryside land. However, the numbers of sluice gates are insufficient in the delta and the water discharge capacity of these sluice gates during high rainfall is very low. The huge pressure of water during climatic extremes suddenly breaks down the system of sluice gate and causes large scale embankment breaching in the delta.

- Embankment acts as a lifeline for deltaic people. It is used as a communication pathway by local habitants. The excessive pressure of transportation often causes structural failure of embankments.

- The use of low-quality materials and faulty construction of embankment 
without understanding the ground hydro-geomorphology often causes embankment failure. Illegal mining, as well as inadequate maintenance and inappropriate land-use, further trigger the problem of embankment breaching.

\section{Management of Embankment Breaching}

The embankments, as public property act as a safeguard for private property in the coastal region (Sarkhel, 2013). However, regular maintenance and strategic planning are required for its management in the long run. At present, different types of management strategies have been taken by IWD to protect the riverbank erosion and embankment breaching (Figure 6).

Most of the river in Gosaba Island follows a meandering path and causes erosion in the outer bank. To protect riverbank erosion porcupines are used in various parts of the delta. Porcupines are a form of a permeable structure made by bamboo or concrete structure to reduce flow and trap sediment (Aamir and Sharma, 2015). They have pole-like projections in all directions that used as flood control structures as well as for river bank and bed protection.

On the river banks, longitudinal protection structures are installed in parallel to the river course to protect the country side land from erosion. It is made by both earthen and concrete materials like cemented bricks and stones. The construction cost of concrete embankments is higher than earthen embankments and has a significant impact on environment.
- Sandbags are often used in the deltaic region to reduce the devastating effects of riverbank erosion. The sandbags wall or barrier is arranged layer by layer to improve the stability of the river bank. The total weight of the sandbags is not more than 14-18 kg which is easier to handle. Some bamboo piles are also used in front of sandbags to give the riverbank more stability.

- Block pitching is a method to protect the river bank from erosion. Blocks are made by bricks or cemented materials and appropriately arranged by maintaining the riverside slope 3:1. The construction of block pitching is quite costly and labour intensive. Highly technical expertise and understanding of the local hydro-geomorphic characteristics of the land is an essential requirement for engineering works.

- Bamboo used in the form of piles to strengthen and stabilise the embankment. The row of bamboo piles firmly fixed with a rope or iron wire. Piling in wet soil of marshy land is very easy but required more strength. In some places, two parallel rows of piles are prepared, and space between them filled with boulders and pebbles to protect embankment from toe erosion.

- Protective layer made by either jute, plastic or tin is used as a protective cover on the erosive concave part of the river bank. It is a very cost-effective and easy way to check temporary riverbank erosion. 


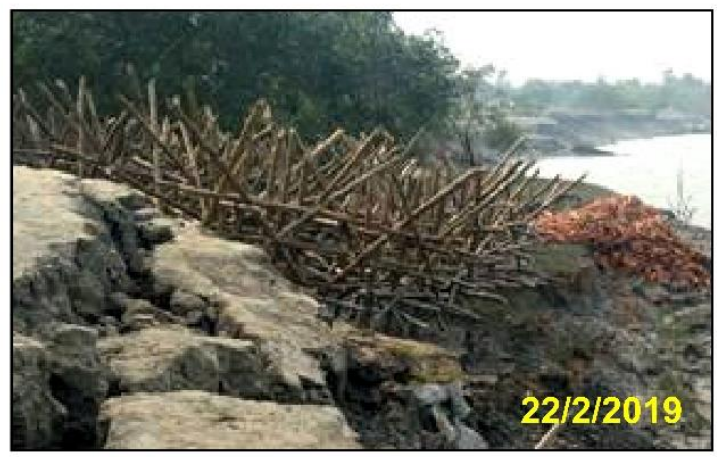

Porcupines made by bamboo Rangabalia

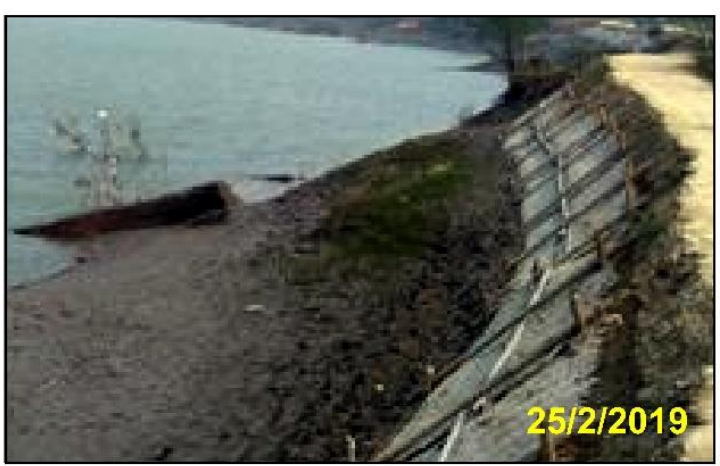

Protective layer

Manmathanagar

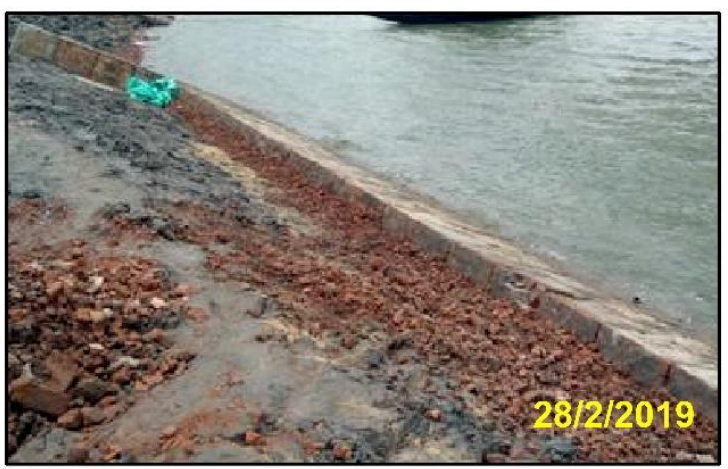

Block pitching

Pakhiralay

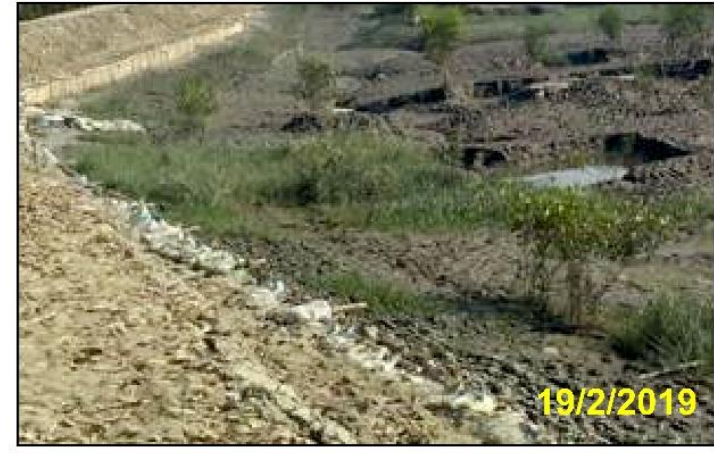

Sandbags protected by bamboo piles Chandipur

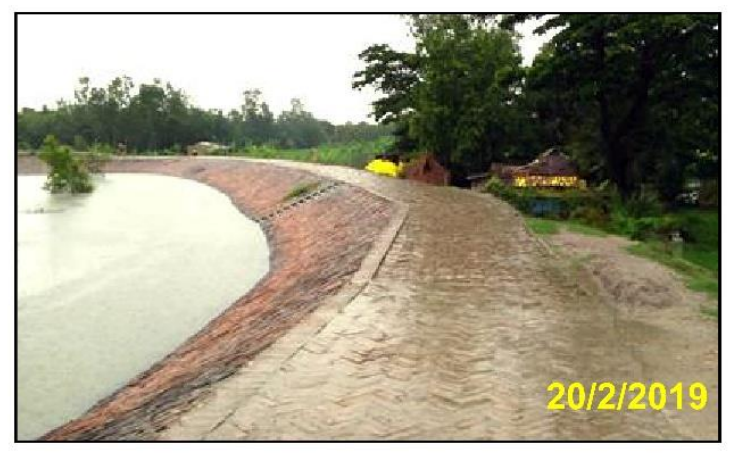

Block pitching

Bijoynagar

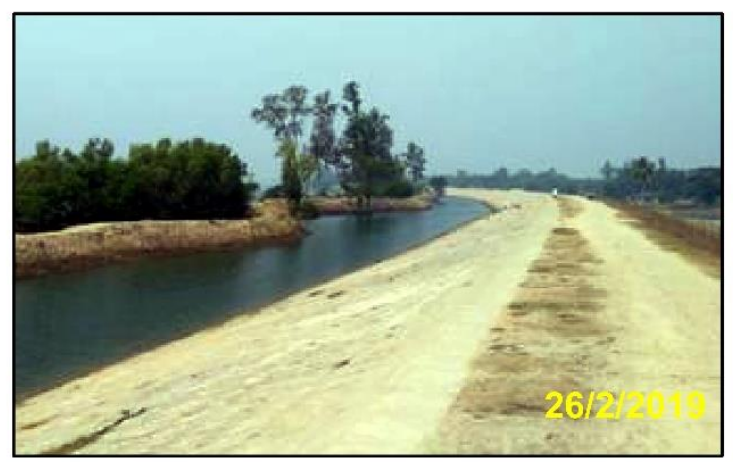

Aila Dam

Bagbagan

Source: Field Survey

Figure 6: Management Strategies for Vulnerable Sites of Embankments Source: Field Survey

\section{Conclusion}

The principal purpose of this research was to understand better embankment breaching and its management on active tidal land of the Gosaba Island geospatially located in South 24
Parganas district of West Bengal. The construction of embankment in the premature delta has been hampered the delta formation process in Sundarban. The choking of river channels increases the tidal magnitude and 
intensity of embankment breaching during climatic extremes. The study reveals that the southern part of the delta specially Rangabellia, Gosaba, Bally, Satjelia including Kumirmari in the east are extremely vulnerable due to intensive river bank erosion. The spatio temporal vulnerability of embankment breaching depends on both natural and anthropogenic factors. The modern engineering method of the embankment is efficient enough to protect river bank from erosion but it is challenging to construct in such a hydro-geomorphologically diversified land. Therefore, traditional methods of embankment construction are often useful in most of the places to protect the vulnerable sites of the river bank which is not efficient enough during the extreme climatic situation. The proper coastal management strategy with community participations urgently need for longevity of embankments. There is a need for strong integration and co-ordination between IWD and Gram Panchayat for successful implementation and conservation of embankments at ground level to save the estuarine people from coastal hazards and disasters.

\section{References}

Aamir, M., \& Sharma, N. (2015). Riverbank Protection with Porcupine System:

Development of Rational Design Methodology. Journal of Hydraulic Engineering, 21(3), 317332. doi.org/10.1080/09715010.2015.1029544

Bagchi, K. (1944). The Ganges Delta. University of Calcutta, 12-57.

Banerjee, A. (1998). Environment, Population and Human Settlement of Sundarban Delta. Concept Publishing Company, 27-32. ISBN: 817022-739-9 Retrieved on 02 April 2019 from, https://books.google.co.in/books?id=zf_xv9LRd $4 c C \& p g=P A 3 \&$ source $=$ gbs_selected_pages\&cad $=3 \# v=$ onepage $\& q \& f=f a l s e$

Census of India, (2011). Provisional Population Totals. Registrar General and Census Commissioner of India, Ministry of Home Affairs, New Delhi, India. Retrieved on 15 March 2019 from, https://censusindia.gov.in/2011census/dchb/D
CHB_A/19/1917_PART_A_DCHB_SOUTH\%20TW ENTY\%20FOUR\%20PARGANAS.pdf

Das, T. K., \& Maity, R. (2008). Land Reclaim and Embankment Breaching- A Case Study along the Raimangal, Sundarban. Changing Scenario of Deltaic Environment, Vidyasagar University, 8488.

Das, T.K., Majee, A., \& Maity, R. (2010). Stress on Embankment As Negative Feedback in the System of Reclaimed Sundarban-A Case Study along the Raimangal. Indian Science Cruiser, 24(1), 24-27.

Das, M., Das, T.K., \& Maity, A. (2012). Managing Embankment Breaching in North-East

Sundarban. acb Publications, Kolkata, 8-17. ISBN: 81-87500-59-X

Das, K., \& Das, K. (2015). Embankment Breaching and its Management in Gosaba and Basanti Blocks of Sundarbans, West Bengal. Indian Journal of Spatial Sciences, 6(1), 49-55.

Das, K. (2016). Sundarban Embankments-A Study along Suryaberia River, Sambhunagar Island, Gosaba, West Bengal. International Journal of Current Research, 8(5), 32187-32195.

Dhara, S., \& Paul, A.K. (2016). Embankment Breaching and Its Impact on Local Community in Indian Sundarban: A Case Study of Some Blocks of South West Sundarban. IJISET, 3(2), 23-32.

District Human Development Report of South 24 Parganas (2009). Development \& Planning Department, Government of West Bengal. 1-20. Retrieved on 12 January 2019 from,

http://www.undp.org/content/dam/india/docs /hdr_south24_parganas_2009_full_report.pdf.

Dutta, S. (2014). Sir Daniel Hamilton and the History of Gosaba. Mitra and Ghosh Publishers, 23-35. ISBN: 978-81-7293-996-0

Ghosh, A., \& Mukhopadhyay, S. (2016). Bank Erosion and Its Management: Case Study in Muriganga-Saptamukhi Interfluves Sundarban, India. Geographical Review of India, 78(2), 146161. DOI 10.1007/s40808-016-0130-x

Ghosh, A., Schmidt, S., Eickert, T. \& Niisser, M. (2015). The Indian Sundarban Mangrove Forests: History, Utilization, Conservation 
Strategies and Local Perception. Diversity, 7, 149-169. doi:10.3390/d7020149

Gopinath, G., \& Seralathan, P. (2005). Rapid

Erosion of the Coast of Sagar Island, West

Bengal, India. Environmental Geology, 48, 1058-1067. DOI: 10.1007/s00254-005-0044-9

Gour, J. (2012). Changing Fluvio-

Gomorphological Environment in the MatlaBidyadhari Interfluves- A Model Unit of Active and Mature Indian Sundarban. Geo-Analyst, 2(1), 1-7.

Kundu, A.K. (2014). Embankment in Sundarban and Reconstruction of Damaged Embankment in Aila. Sechpatra, Waterways and Irrigation Department, Government of West Bengal, pp. 19-25.

Lakshmi, S.A., \& Edward, J.K.P. (2010). Coastal Issues and Management Strategy for Sagar Island in Bay of Bengal. Recent Research in Science and Technology, 2(5), 96-101. ISSN 207776-5061

Maity, R., Das, T.K., \& Majee, A. (2012). Managing Embankment Breaching in NorthEast Sundarban, Community Awareness in Sundarban. S. Chatterjee (Eds). Acb Publication, Kolkata, India, 8-17.

Mistri, B. (2014). Construction of Closure on Tidal Creeks and its Effects: A Case Study of Pathar Pratima CD Block of Sundarban. Nature and Sustainable Development-Impact of Green Accounting, Published by Academic Staff College, the University of Burdwan, 111-124.

O'Mally, L. S.S. (1914). Rivers of Bengal, Bengal District Gazetteers. The Bengal Secretariat Book Depot. pp 1-31.
Sarkar, H., Roy, A., \& Siddique, G. (2016). Impact of Embankment Breaching and Rural Livelihood: A Case Study in Ghoramara Island of the Sundarbans Delta in South 24 Parganas. The Journal of Bengal Geographer, 5 (4), 97-117.

Sarkhel, P. (2012). Examining Private

Participation in Embankment Maintenance in the Indian Sundarban. Published by the South Asian Network for Development and Environmental Economics (SANDEE), SANDEE Working Paper No. 75-12, 1-24.

Sarkhel, P. (2013). Policy Brief Based on SANDEE Working Paper No. 75-12,'Examining Private Participation in Embankment Maintenance in the Indian Sundarban by Prasenjit Sarkhel. Department of Economics, University of Kalyani, West Bengal. India, 1-4. Retrieved on 17 March 2019from, https://ideas.repec.org/p/ess/wpaper/id5353.h tml

Srivastava, A., Niu, X., Di, K., \& Li, R. (2005). Shoreline Modeling and Erosion Prediction, ASPRS 2005 Annual Conference 'Geospatial Goes Global: From Your Neighborhood to the Whole Planet' March 7-11, 2005, Baltimore, Maryland

The World Wide Fund for Nature (WWF) Report. (2010). Sundarban: Future Imperfect Climate Adaptation Report Edited By Anurag Danda, pp. 1-2. Retrieved on 14 November 2018 from,

https://assets.wwfindia.org/downloads/sundar bans_future_imperfect_climate_adaptation_r eport.pdf 